\title{
Selection of shrimp breeders free of white spot syndrome and infectious hypodermal and hematopoietic necrosis
}

\author{
Carlos Cesar de Mello Junior ${ }^{(1)}$, Gael Yvan Leclercq Delsol(1), Emmerik Motte(1), Virna Alexia Cedeño Escobar ${ }^{(1)}$, \\ Pedro Filipe Rey(1), Mauricio Laterça Martins ${ }^{(2)}$, Luis Alejandro Vinatea Arana ${ }^{(3)}$, Giovanni Lemos de Mello(4), \\ Alvaro Pestana de Farias ${ }^{(5)}$, Xavier Antonio Serrano Arguello(1) and John Erick Montaño Maridueña(1)
}

(1)Concepto Azul, Cdla. Vernaza Norte, Mz, no 10, Villa 34, Guayaquil, Ecuador. E-mail: carlosjrmello@hotmail.com.br gael_leclercq@yahoo.com, motte.emmerik@gmail.com, virnalexia.cedeno@gmail.com, pedrocean@yahoo.com.br, xaviersx2000@hotmail.com, johnerickmont@hotmail.com (2)Universidade Federal de Santa Catarina (UFSC), Centro de Ciências Agrárias (CCA), Departamento de Aquicultura, Laboratório de Sanidade de Organismos Aquáticos, Rodovia Admar Gonzaga, no 1.346, Itacorubi, CEP $88040-900$ Florianópolis, SC, Brazil. E-mail: mlaterca@cca.ufsc.br (3)UFSC, CCA, Departamento de Aquicultura, Laboratório de Camarões Marinhos. E-mail: vinatea@mbox1.ufsc.br ${ }^{(4)}$ Empresa de Pesquisa e Extensão Rural de Santa Catarina, Centro de Desenvolvimento em Aquicultura e Pesca, Campo Experimental de Piscicultura de Camboriú, Rua Joaquim Garcia, s/no, Centro, CEP 8340-000 Camboriú, SC, Brazil. E-mail: giovannimello@epagri.sc.gov.br ${ }^{(5)}$ Aquaconsult - Aquicultura e Meio Ambiente Ltda., Rua Gustavo Richard, no 550, Sala 9, Centro, CEP 88790-000 Laguna, SC, Brazil. E-mail: alvaropfarias@gmail.com

Abstract - The objective of this work was to select surviving breeders of Litopenaeus vannamei from white spot syndrome virus (WSSV) outbreak, adapted to local climatic conditions and negatively diagnosed for WSSV and infectious hypodermal and hematopoietic necrosis virus (IHHNV), and to evaluate if this strategy is a viable alternative for production in Santa Catarina, Brazil. A total of 800 males and 800 females were phenotypically selected in a farm pond. Nested-PCR analyses of 487 sexually mature females and 231 sexually mature males showed that $63 \%$ of the females and 55\% of the males were infected with IHHNV. Animals free of IHHNV were tested for WSSV, and those considered double negative were used for breeding. The post-larvae produced were stocked in nine nursery tanks for analysis. From the 45 samples, with 50 post-larvae each, only two were positive for IHHNV and none for WSSV. Batches of larvae diagnosed free of virus by nested-PCR were sent to six farms. A comparative analysis was carried out in growth ponds, between local post-larvae and post-larvae from Northeast Brazil. Crabs (Chasmagnathus granulata), blue crabs (Callinectes sapidus), and sea hares (Aplysia brasiliana), which are possible vectors of these viruses, were also evaluated. The mean survival was $55 \%$ for local post-larvae against $23.4 \%$ for post-larvae from the Northeast. Sea hares showed prevalence of $50 \%$ and crabs of $67 \%$ of WSSV.

Index terms: Litopenaeus vannamei, breeding, epidemiology, nested-PCR.

\section{Seleção de reprodutores de camarão livres da síndrome da mancha-branca e da necrose infecciosa hipodermal e hematopoiética}

\begin{abstract}
Resumo - O objetivo deste trabalho foi selecionar reprodutores de Litopenaeus vannamei sobreviventes de um surto do vírus da síndrome da mancha-branca (WSSV), adaptados às condições locais e diagnosticados negativamente para WSSV e para o vírus da necrose infecciosa hipodermal e hematopoiética (IHHNV), e avaliar se esta extratégia é uma alternativa viável para produção em Santa Catarina. Foram selecionados fenotipicamente 800 machos e 800 fêmeas, de um viveiro. Análises de nested-PCR de 487 fêmeas e de 231 machos, sexualmente maduros, mostraram que $63 \%$ das fêmeas e $55 \%$ dos machos estavam infectados com IHHNV. Os animais livres de IHHNV foram testados para WSSV, e os considerados duplo negativos destinados à reprodução. As pós-larvas produzidas foram estocadas em nove berçários, para análise. Das 45 amostras, com 50 pós-larvas cada, apenas duas foram positivas para IHHNV e nenhuma para WSSV. Os lotes de pós-larvas diagnosticadas livres de vírus por nested-PCR foram encaminhados para seis fazendas. Foi realizada análise comparativa em viveiros de engorda, entre pós-larvas locais e pós-larvas do Nordeste do Brasil. Também foram analisados caranguejos (Chasmagnathus granulata), siris (Callinectes sapidus) e lebres do mar (Aplysia brasiliana), que são possíveis vetores dos vírus. A média de sobrevivência foi de 55\% para as pós-larvas locais e de $23,4 \%$ para as pós-larvas do Nordeste. As lebres do mar apresentaram prevalência de 50\% e os caranguejos de $67 \%$ de WSSV.
\end{abstract}

Termos para indexação: Litopenaeus vannamei, reprodução, epidemiologia, nested-PCR.

\section{Introduction}

Infectious diseases significantly affect marine shrimp culture throughout different life stages, causing mortality and reducing growth rates (Lightner, 1999). In Brazil, the main pathogenic agents are: infectious hypodermal and hematopoietic necrosis virus (IHHNV), reported across the country (Moser

Pesq. agropec. bras., Brasília, v.46, n.5, p.531-537, maio 2011 
et al., 2005; Braz et al., 2009); infectious myonecrosis virus (IMNV), found in the Northeast region (Senapin et al., 2007); and white spot syndrome virus (WSSV), registered in the state of Santa Catarina, in the South region (Seiffert, 2005).

The rapid transmission of WSSV in culture systems may be caused by infected shrimp or infected water, by cannibalism of lethargic shrimp (Chang et al., 1996), or by other vectors, such as zooplancton, crustaceans, and microalgae, according to the Office International des Epizooties (2006). However, the main sources of infection in shrimp farms are brood stocks and infected post-larvae (Sánchez-Martínez et al., 2007).

The transmission of IHHNV is rapid and efficient due to cannibalism of lethargic animals, but significantly lower by cohabitation (Soto \& Lotz, 2001). Vertical transmission is common from breeder to larvae (Office International des Epizooties, 2006), in which the infected female ovaries are the source of transmission; interestingly, sperm is generally virus-free (Motte et al., 2003). According to Motte et al. (2003), vertical transmission of IHHNV may be an important factor in increasing the prevalence of the virus from generation to generation in cultured shrimp. Breeders are one of the key factors in viral vertical transmission, which favors horizontal transmission in growth ponds. A possible explanation is that, since the majority of infected animals survive with no clinical symptoms, most of them are selected for breeding from apparently healthy shrimp. However, these offspring could be heavily infected by IHHNV and present a high risk of transmission to their descendents. In several countries, it has been shown that the use of sensitive shrimp, selected with no pathogen resistance criteria, to develop new brood stocks, endangers the sustainability of the shrimp industry (Briggs et al., 2004).

The selection and production of larvae based on resistance and sanitary criteria has been effective in culture systems (Chamorro \& Mialhe, 2004). The first level of resistant shrimp selection consists in selecting the survivors of natural infections in culture growth ponds. Specific pathogen resistant (SPR) strains of Litopenaeus vannamei (Boone, 1931) have high genetic diversity and are from specific pathogen-free (SPF) and non SPF sources. These strains have been successfully selected based on the survival rate after epidemic outbreaks in growth ponds for up to five years, in Colombia, Ecuador, Panama, and Northeast Brazil, and show higher resistance than those exclusively from SPF sources (Briggs et al., 2004; Cock et al., 2009).

The introduction of SPF strains from other countries is risky, since they may be hosts to unknown viral pathogens. In spite of being SPF, these strains may still be positive for the pathogen depending on the sensitivity of the diagnosis method (Do et al., 2006; Montgomery-Brock et al., 2007) or on the stressful conditions to which animals are exposed (Vieira et al., 2007).

Several approaches, such as eliminating the source of infection, cutting off the pathways for the transmission of infection, controlling water quality, and enhancing disease resistance in shrimps, are used to control WSSV; however, in endemic areas, these measures are not enough to face the challenge of this virus (Huang et al., 2011).

The objective of this work was to select surviving breeders of $L$. vannamei from white spot syndrome virus (WSSV) outbreak, adapted to local climatic conditions and negatively diagnosed for WSSV and infectious hypodermal and hematopoietic necrosis virus (IHHNV), and to evaluate if this strategy is a viable alternative for production in Santa Catarina, Brazil.

\section{Materials and Methods}

The experiment was carried out with local post-larvae and post-larvae from Northeast Brazil. The local stock was obtained from six shrimp farms. Farms 1, 2, 4, 5, and 6, are located at the Laguna estuarine system in the state of Santa Catarina, South Brazil (between $28^{\circ} 18^{\prime}$ and $28^{\circ} 55^{\prime} \mathrm{S}, 48^{\circ} 67^{\prime}$ and $48^{\circ} 88^{\prime} \mathrm{W}$ ), and are exposed to the same climatic conditions. Farm 3 is the only one located outside the Laguna estuarine system, in the city

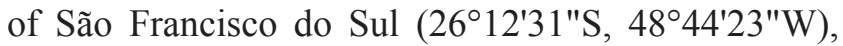
characterized by a more stable climatic condition.

Initially, 30 shrimp, were randomly sampled: 28 females and 2 males, from the commercial shrimp farm at the Laguna estuarine system, harvested during the shrimp reproduction stage. These animals were survivors of the last WSSV outbreak in 2006/2007. According to World Organization for Animal Health (Office International des Epizooties, 2006), the number of shrimp collected is acceptable for standard sampling of shrimp grown in ponds to estimate virus prevalence with a $95 \%$ confidence limit. 
Before tissue sampling, shrimp were measured, gendered, and their health status was evaluated by external observation. The hepatopancreas and a pair of pleopods were removed from each shrimp, fixed in $90 \%$ ethanol, and analyzed by nested-PCR for determination of WSSV, IHHNV, and intracellular bacteria of necrotizing hepatopancreatitis (NHP), and by RT-nested-PCR for IMNV. According to Lo et al. (1997), pleopods are considered an efficient tissue sample for diagnosis.

After epidemiological assessment of future brood stock, 800 males and 800 females were phenotypically selected from the same pond to detect clinical signs of any pathology, and to establish an equivalent proportion between genders among weighed shrimps. The shrimps were transferred to the Estaleirinho shrimp hatchery in Camboriú, Santa Catarina (272'53"S, $48^{\circ} 35^{\prime} 15^{\prime \prime} \mathrm{W}$ ), in standard transport aquaculture boxes made from fiberglass, with oxygen supply. The boxes were acclimated, and the shrimp kept and separated by gender in different tanks. Water temperature in tanks was maintained at $28 \pm 1^{\circ} \mathrm{C}$, with daily replacement of $200 \%$ of fresh water and with air supply, as described in rearing management manuals (Food and Agriculture Organization of the United Nations, 2003).

Females were subjected to the ablation process ten days after arrival at the hatchery. After ablation and the first spawning, 487 females were eye tagged with a numbered ring. Males were selected by their weight and spermatophore development, and 231 males were eye tagged with a different color of numbered ring.

All eye-tagged shrimps had one pair of pleopods removed and preserved in $90 \%$ ethanol for analysis by nested-PCR. The breeders were individually analyzed by nested-PCR for IHHNV, and the negatively diagnosed animals were analyzed for WSSV. Analysis for IMNV was performed for security, since this pathogen has not yet been reported in South Brazil. After this procedure, the sexually mature pathogen-free shrimp were distributed in couples in the breeding tanks and transferred to nauplii production. Positive animals for WSSV and IHHNV were immediately discarded.

The diagnosis procedure was done at the Concepto Azul Laboratory in Guayaquil, Ecuador, using the Concepto Azul Kit. In the case of larvae, DNA was extracted from body homogenates using lysis buffer $(0.05 \mathrm{~N}$ of $\mathrm{NaOH} ; 0.25 \%$ of SDS). This DNA extraction protocol had been previously validated for these types of tissues by PCR analysis with primers corresponding to penaeidin (Destoumieux et al., 2000). In the case of juvenile or adult shrimps, DNA extraction was performed using the same protocol from tissue samples collected with a $1 \mathrm{~mL}$ tuberculin syringe and a $27 \mathrm{G} \times 1 / 2$ needle using a sodium citrate solution $\left(10 \%, \mathrm{w} \mathrm{V}^{-1}\right)$ as an anticoagulant. Two steps of nested-PCR were carried out following the Concepto Azul Kit instructions. DNA amplification was done according to a double tube method with preheating for $3 \mathrm{~min}$ at $94^{\circ} \mathrm{C}$ and 35 cycles for $30 \mathrm{~s}$ at $94^{\circ} \mathrm{C}, 45 \mathrm{~s}$ at $56^{\circ} \mathrm{C}$, and $45 \mathrm{~s}$ at $72^{\circ} \mathrm{C}$. Positive controls consisted of DNA extracted from purified virus suspensions. The second PCR analysis was carried out using the same protocol with $1 \mu \mathrm{L}$ DNA obtained from previous amplification. Amplified fragments were observed after electrophoresis in 2\% agarose gel.

When infected shrimp cohabit with healthy ones in the same tanks, the transmission of WSSV by cohabitation in L. vannamei is approximately $0.01 \%$, while the transmission rate by ingestion is $46 \%$ (Soto \& Lotz, 2001). Therefore, the risk of WSSV transmission by cohabitation among live animals is very small (Soto \& Lotz, 2001).

The local hatchery, Estaleirinho, followed standard water quality parameters for commercial hatcheries, i.e., water temperature of $28^{\circ} \mathrm{C}$ and salinity of $34 \mathrm{ppt}$ (Food and Agriculture Organization of the United Nations, 2003). Before being sent to the farms, larvae were analyzed by nested-PCR for determination of WSSV, IHHNV, Baculovirus penaei (BP) and NHP, and by RT nested-PCR for IMNV. A total of 4,214,000 post-larvae stage 18 (PL-18), divided into seven nurseries, were used. Two hatchery tanks with PL-8 were sampled, totalizing nine post-larvae tanks. Five samples, with 50 animals each, were collected from each tank, totalizing 45 samples, which were fixed in $90 \%$ ethanol.

Nauplii 5 were imported from Northeast Brazil to be tested in local production conditions at the Estaleirinho hatchery. The nauplii were from the Aquatec hatchery, located at Canguaretama, Rio Grande do Norte State $\left(6^{\circ} 17^{\prime} 55^{\prime \prime} \mathrm{S}, 35^{\circ} 2^{\prime} 1 " \mathrm{~W}\right)$, and were previously analyzed by Santa Catarina's official state organ of animal health control - Companhia Integrada de Desenvolvimento Agrícola de Santa Catarina - for the presence of viral pathogens. The methodology used followed the standard protocols described in the 
manual of diagnostic tests for aquatic animals (Office International des Epizooties, 2006). After the analysis and negative diagnosis, the nauplii were subjected to the protocols of the Estaleirinho laboratory until they were sent to the shrimp farms.

In order to determine the presence of viral pathogens in the shrimp farms, dead and live shrimp were randomly collected in shrimp farms 1, 2, 3, and 4. Farm 1, under a monoculture system, was stocked with local larvae, and 45 shrimps were collected in four different grow-out ponds. In farm 2, characterized as a polyculture system with Nile tilapia (Oreochromis niloticus), ten dead shrimp were found and collected from two grow-out ponds. Five ponds were stocked with local larvae and five with post-larvae from the Northeast. In farm 3, 25 local larvae were evaluated. In farm 4, ten dead shrimp from a pond with larvae brought from the Northeast were analyzed. Possible vectors, such as crabs [Chasmagnathus granulata (Dana, 1851)], blue crabs (Callinectes sapidus (Rathbun, 1896)), and sea hares [(Aplysia brasiliana (Rang, 1828)], were also captured when found on this farm.

In farms 3,5 , and 6 , a comparative survival study was carried out between local larvae and Northeast larvae. Ponds in each farm were stocked on the same date and had the same stocking density. During this period, salinity was 10 to $25 \mathrm{ppt}$ and surface water temperature, measured in the morning, was 23.0 to $24.9^{\circ} \mathrm{C}$.

In farm 3, two ponds were selected and stocked at a density of 15 shrimp per square meter. One pond was stocked with larvae from the Northeast and the other with pathogen-free larvae. In farm 5, 11 ponds were stocked at a density of ten shrimp per square meter, eight with Northeast larvae and three with local larvae. In farm 6, three ponds were selected and stocked at a density of five shrimp per square meter, one with Northeast larvae and the others with local larvae. The survival rate in the farms was analyzed by Student's $t$ test, at $5 \%$ probability.

\section{Results and Discussion}

Of the 22 females selected, four were positive for IHHNV, which means $18 \%$ of prevalence. However, males did not show viral prevalence. The prevalence of IHHNV in 30 pre-brooders was $13 \%$. No animal was infected by WSSV.
After the ablation process and the first spawning, 307 (63\%) out of 487 examined females were positive for IHHNV and negative for WSSV. From 231 males, 127 (55\%) were positive for IHHNV and negative for WSSV. Therefore, 180 (37\%) females and 104 (45\%) males free of IHHNV and WSSV were used.

IHHNV is not responsible for mass mortality in L. vannamei, which favors the dissemination of the virus throughout generations (Office International des Epizooties, 2006). In the present study, the prevalence of IHHNV in females was $18 \%$ before ablation and the first spawning, and $63 \%$ after hatchery management, which corroborates the observations of Hsu et al. (1999), Peng et al. (2001), and Motte et al. (2003). According to Peng et al. (2001), spawning can induce WSSV replication in Penaeus monodon. Motte et al. (2003) used nested-PCR to evaluate the prevalence of IHHNV in females of $L$. vannamei, before and after spawning. The authors found a 19 and $31 \%$ prevalence of IHHNV before and after the first spawning, respectively. Based on these results, spawning can cause viral replication. In another study, Hsu et al. (1999) observed that some females analyzed by nested-PCR were negatively diagnosed for WSSV, before spawning, and positively diagnosed after spawning.

By preventing the vertical transmission of IHHNV, it is possible to gradually increase shrimp production in ponds and to reach better health control for this pathogen in two or three generations, as verified by Motte et al. (2003).

No breeders were positively diagnosed for WSSV, even after ablation and the first spawning, which suggests that the survivors from outbreaks could have some viral resistance (Gitterle, 1999). A probable explanation is that the viral load of these animals is too small to be detectable by nested-PCR or that it is impossible to guarantee that all the shrimp ingested infected tissue in the growth pond. The experimental challenge of shrimps with WSSV could be done by oral or injection methods for a more uniform infection and a higher selection pressure (Gitterle et al., 2006).

Forty-three out of the 45 samples from nine nursery tanks were negative for WSSV, IHHNV, IMNV, BP and NHP, whereas two were positive for IHHNV on the second reaction of nested-PCR. This result can be considered a light infection (Sahtout et al., 2001) or a small positive result (Sritunyalucksana et al., 2010). 
Viral load in females at the time of the first analysis by nested-PCR was probably too low and, after some spawning, resulted in virus replication. According to Hsu et al. (1999) Peng et al. (2001) and Motte et al. (2003), successive spawns can induce viral reversion in shrimp females. However, the reduction of vertical transmission through brood stock certification by PCR is only significant in one generation. Monitoring tests should be performed on females with higher spawning numbers in order to detect the presence of viruses in these animals and to eliminate the infected brood stock. Further studies should be carried out to clarify the detailed mechanisms of viral reversion.

From the 45 shrimp analyzed in farm 1, 2.2\% were infected with WSSV and IHHNV. In farms 2 and 3, the results were negative for both viruses. In farm 4, a prevalence of $10 \%$ was related for WSSV and IHHNV. Regarding possible vectors, sea hares and crabs showed $50 \%$ and $67 \%$ of prevalence for WSSV, respectively (Table 1).

In the case of WSSV, virus eradication is unlikely, since the pathogen is already found in the natural environment of Santa Catarina (Marques, 2007). The virus has natural reservoirs in ponds, including crabs, copepods, microalgae, zooplankton, and the soil (Office International des Epizooties, 2006).

In a first-time report, sea hares were positively diagnosed for WSSV, reinforcing the importance of vectors in viral cycles. Epidemiological analysis in live and dead shrimp confirms the hypothesis of contaminated environment, since no breeders and post-larvae were diagnosed positively for WSSV. These animals were probably contaminated in ponds by natural vectors.

All analyzed farms showed significant difference between the survival rate of local post-larvae and Northeast post-larvae (Table 2). In farm 3, the pond harvested with local larvae showed a $68 \%$ survival rate, and the pond stocked with Northeast post-larvae showed a $53 \%$ survival rate $(\mathrm{p}=0.0278)$. In farm 5 , the survival rate for local larvae and for Northeast post-larvae was 43 and $11 \%$, respectively $(\mathrm{p}=0.0001)$, while in farm 6 , the survival rate for local larvae and for Northeast post-larvae was $54.1 \%$ and $5.6 \%$, respectively $(\mathrm{p}=0.0002)$.

The grow-out periods began during the summer (December to February) and continued throughout autumn (May to June); the surface water temperature varied from 23.1 to $35.5^{\circ} \mathrm{C}$, and the daily change in surface water temperature was around $4.3^{\circ} \mathrm{C}$.

As observed in farms 3, 5, and 6, animals adapted to the local climate showed better survival, probably because they were better adapted to the changes in water temperature. This adaptation possibly delayed immunosuppression (Cock et al., 2009), reducing infection by WSSV. In farm 3, there was a significant difference between the survival rate of local and Northeast post-larvae, probably due to the farm location in a region that was not affected by WSSV and has a higher climatic stability; the highest change in surface water temperature in a day was $3.1^{\circ} \mathrm{C}$. The greatest difference in survival between local larvae and larvae from the Northeast was observed in farm 6 , since this farm is located in the Laguna estuarine system, the area with the highest WSSV impact and the largest daily variation in surface water temperature $\left(5^{\circ} \mathrm{C}\right)$.

Regardless of their source and quality, post-larvae may be exposed to pathogens in endemic regions. Imported SPF strains, considered pathogen free, are automatically challenged when introduced in the culture environment by the amplitude of the local temperature and the local pathogens (Briggs, 2005). Larvae from Northeast Brazil are not inferior, but are adapted to a

Table 1. Infected animals ratio (infected/examined animals), and prevalence rate (in parentheses) for white spot syndrome virus (WSSV) and infectious hypodermal and hematopoietic necrosis virus (IHHNV), in farms 1, 2, 3, and 4.

\begin{tabular}{|c|c|c|c|c|c|c|c|c|}
\hline \multirow[t]{2}{*}{ Farm } & \multicolumn{2}{|c|}{ Shrimp } & \multicolumn{2}{|c|}{ Crab } & \multicolumn{2}{|c|}{ Sea hare } & \multicolumn{2}{|c|}{ Blue crab } \\
\hline & WSSV & IHHNV & WSSV & IHHNV & WSSV & IHHNV & WSSV & IHHNV \\
\hline 1 & $45 / 1(2.2)$ & $45 / 1(2.2)$ & $0 / 0$ & $0 / 0$ & $0 / 0$ & $0 / 0$ & $0 / 0$ & $0 / 0$ \\
\hline 2 & $10 / 0$ & $10 / 0$ & $0 / 0$ & $0 / 0$ & $0 / 0$ & $0 / 0$ & $0 / 0$ & $0 / 0$ \\
\hline 3 & $25 / 0$ & $25 / 0$ & $0 / 0$ & $0 / 0$ & $0 / 0$ & $0 / 0$ & $0 / 0$ & $0 / 0$ \\
\hline 4 & $10 / 1(10)$ & $10 / 1(10)$ & $3 / 0$ & $3 / 0$ & $6 / 3(50)$ & $6 / 0$ & $3 / 2(67)$ & $3 / 0$ \\
\hline Total & $90 / 2(2.2)$ & $90 / 2(2.2)$ & $3 / 0$ & $3 / 0$ & $6 / 3(50)$ & $6 / 0$ & $3 / 2(67)$ & $3 / 0$ \\
\hline
\end{tabular}


Table 2. Comparative analyzes of the survival rate between local post-larvae, subjected to vertical transmission prevention procedure, and post-larvae from Northeast Brazil $^{(1)}$.

\begin{tabular}{lcccc}
\hline Farm & Source & Ponds & Stocking density (shrimp) & Survival rate (\%) \\
\hline 3 & Local & 2 & 15 & 68 \\
3 & Northeast & 3 & 15 & 53 \\
5 & Local & 3 & 10 & $43.0 \mathrm{a}$ \\
5 & Northeast & 8 & 10 & $11.8 \mathrm{~b}$ \\
6 & Local & 2 & 5 & 54.1 \\
6 & Northeast & 1 & 5 & 5.6 \\
\hline
\end{tabular}

(1)Means followed by different letters in the column differ by Student's $\mathrm{t}$ test, at $5 \%$ probability.

different environment, which may explain their lower performance in ponds in South Brazil Region.

Preserving and improving local genetic stocks, adapted to local environmental conditions and exposed to natural selection pressures, is necessary to develop local resistant strains. Farmers must also improve and apply practices to exclude or minimize stressful conditions in shrimp ponds.

\section{Conclusion}

Preventing vertical transmission of infectious hypodermal and hematopoietic necrosis virus (IHHNV) and white spot syndrome virus (WSSV) by selecting surviving breeders of Litopenaeus vannamei from WSSV outbreak, adapted to local climatic conditions and negatively diagnosed for IHHNV and WSSV, increases shrimp production in ponds and controls these viruses, after two or three generations.

\section{Acknowledgements}

To Associação Catarinense dos Criadores de Camarão, Concepto Azul, Aquaconsult, and Laboratório Estaleirinho, for financial support and for providing field collections; to Conselho Nacional de Desenvolvimento Científico e Tecnológico, for scholarship granted; and to Dr. Afonso Celso Dias Bainy from Universidade Federal de Santa Catarina, and Dr. Alitiene Moura Lemos Pereira from Empresa Brasileira de Pesquisa Agropecuária, for critical review of the manuscript.

\section{References}

BRAZ, R. de F. dos S.; SILVA, C.P.R. de O. da; REIS, L.G.; MARTINS, P.C.C.; SALES, M.P. de; MEISSNER, R.V. Prevalence of infectious hypodermal and hematopoietic necrosis virus (IHHNV) in Penaeus vannamei cultured in northeastern Brazil. Aquaculture, v.288, p.143-146, 2009.

BRIGGS, M.; FUNGE-SMITH, S.; SUBASINGHE, R.; PHILLIPS $M$. Introductions and movement of Penaeus vannamei and Penaeus stylirostris in Asia and the Pacific. Bangkok: Food and Agriculture Organization of the United Nations, 2004. 99p.

BRIGGS, M.; FUNGE-SMITH, S.; SUBASINGHE, R.P.; PHILLIPS, M. Introductions and movement of two penaeid shrimp species in Asia and the Pacific. Rome: Food and Agriculture Organization of the United Nations, 2005. 78p. (FAO fisheries technical paper, 476).

CHAMORRO, R.; MIALHE, E. Programa de prevención de enfermedades y mejoramiento genético del camarón Litopenaeus vannamei en Panamá. Panorama Acuícola, jun. 2004. Disponible en: <http://www.panoramaacuicola.com/noticias. html? pageNum $=1 \&$ fecha $=2004-06>$. Accedido el: 31 mayo 2011.

CHANG, P.S.; LO, C.F.; WANG, Y.C.; KOU, G.H. Identification of white spot syndrome associated baculovirus WSBV target organs in the shrimp Penaeus monodon by in situ hybridization. Diseases of Aquatic Organisms, v.7, p.131-139, 1996.

COCK, J.; GITTERLE, T.; SALAZAR, M.; RYE, M. Breeding for disease resistance of Penaeid shrimps. Aquaculture, v.286, p.1-11, 2009.

DESTOUMIEUX, D.; MUNÕS, M.; COSSEAU, C.; RODRIGUEZ, J.; BULET, P.; COMPS, M.; BACHERE, E. Penaeidins, antimicrobial peptides with chitin-binding activity are produced and stored in shrimp granulocytes and released after microbial challenge. Journal of Cell Science, v.113, p.461-469, 2000.

DO, J.W.; CHA, S.J.; LEE, N.S.; KIM, Y.C.; KIM, J.W.; KIM, J.D.; PARK, J.W. Taura syndrome virus from Penaeus vannamei shrimp cultured in Korea. Diseases of Aquatic Organisms, v.70, p.171-174, 2006.

FOOD AND AGRICULTURE ORGANIZATION OF THE UNITED NATIONS. Health management and biosecurity maintenance in white shrimp (Penaeus vannamei) hatcheries in Latin America. Rome: FAO, 2003. 58p. (FAO fisheries technical paper, 450).

GITTERLE, T. Evaluación de la resistencia de diferentes poblaciones del camarón marino Litopenaeus vannamei (Boone 1931) al virus del síndrome del Taura (TSV) bajo condiciones controladas. 1999. 74p. Tesis (Doctorado) - Universidad Jorge Tadeo Lozano, Bogotá.

GITTERLE, T.; GJERDE, B.; COCK, J.; SALAZAR, M.; RYE, M.; VIDAL, O.; LOZANO, C.; ERAZO, C.; SALTE, R. Optimization of experimental infection protocols for the estimation of genetic parameters of resistance to White Spot Syndrome Virus (WSSV) in Penaeus (Litopenaeus) vannamei. Aquaculture, v.261, p.501-509, 2006. 
HSU, H.C.; LO, C.F.; LIN, S.C.; LIU, K.F.; PENG, S.E.; CHANG, Y.S.; CHEN, L.L.; LIU, W.J.; KOU, G.H. Studies on effective PCR screening strategies for white spot syndrome virus (WSSV) detection in Penaeus monodon breeders. Diseases of Aquatic Organisms, v.39, p.13-19, 1999.

HUANG, Y.-C.; YIN, Z.-X.; HUA-SHU, A.; HUANG, X.-D.; LI, S.-D.; WENG, S.-P.; HE, J.-G. Characterization of WSSV resistance in selected families of Litopenaeus vannamei. Aquaculture, v.311, p.54-60, 2011.

LIGHTNER, D.V. The penaeid shrimp viruses TSV, IHHNV, WSSV, and YHV: current status in the Americas, available diagnostic methods, and management strategies. Journal of Applied Aquaculture, v.9, p.27-52, 1999.

LO, C.F.; HO, C.H.; CHEN, C.H.; LIU, K.F.; CHIU, Y.L.; YEH, P.Y.; PENG, S.E.; HSU, H.C.; LIU, H.C.; CHANG, C.F.; SU, M.S.; WANG, C.H.; KOU, G.H. Detection and tissue tropism of white spot syndrome baculovirus (WSBV) in captured brooders of Penaeus monodon with a special emphasis on reproductive organs. Diseases of Aquatic Organisms, v.30, p.53-72, 1997.

MARQUES, J. Contribuição para o monitoramento do vírus da síndrome da mancha branca na carcinicultura de Santa Catarina. 2007. 51p. Dissertação (Mestrado) -Universidade Federal de Santa Catarina, Florianópolis.

MONTGOMERY-BROCK, D.; TACON, A.G.J.; POULOS, B.; LIGHTNER, D. Reduced replication of infectious hypodermal and hematopoietic necrosis virus (IHHNV) in Litopenaeus vannamei held in warm water. Aquaculture, v.265, p.41-48, 2007.

MOSER, J.R. Respostas bioquímicas do camarão-branco, Litopenaeus vannamei (Boone, 1931), exposto ao inseticida carbofuran e determinação da prevalência natural do vírus da necrose hipodermal e hematopoietica infecciosa - IHHNV. 2005. 75p. Dissertação (Mestrado) - Universidade Federal de Santa Catarina, Florianópolis.

MOTTE, E.; YUGCHA, E.; LUZARDO, J.; CASTRO, F.; LECLERCQ, G.; RODRÍGUEZ, J.; MIRANDA, P.; BORJA, O.; SERRANO, J.; TERREROS, M.; MONTALVO, K.; NARVÁEZ, A.; TENORIO, N.; CEDEÑO, V.; MIALHE, E.; BOULO, V.
Prevention of IHHNV vertical transmission in the white shrimp Litopenaeus vannamei. Aquaculture, v.219, p.57-70, 2003.

OFFICE INTERNATIONAL DES EPIZOOTIES. Diagnostic manual for aquatic animal diseases. Paris: OIE, 2006.

PENG, S.E.; LO, C.F.; LIN, S.C.; CHEN, L.L.; CHANG, Y.S.; LIU, K.F.; SU, M.S.; KOU, G.H. Performance of WSSV-infected and WSSV-negative Penaeus monodon postlarvae in culture ponds. Diseases of Aquatic Organisms, v.46, p.165-172, 2001.

SAHTOUT, A.H.; HASSAN, M.D.; SHARIFF, M. DNA fragmentation, an indicator of apoptosis, in cultured black tiger shrimp Penaeus monodon infected with white spot syndrome virus (WSSV). Diseases of Aquatic Organisms, v.44, p.155-159, 2001.

SÁNCHEZ-MARTÍNEZ， J.G.; AGUIRRE-GUZMÁN， G.; MEJÍA-RUÍZ, H. White spot syndrome virus in cultured shrimp: a review. Aquaculture Research, v.38, p.1339-1354, 2007.

SEIFFERT, W.Q. A mancha branca em Santa Catarina. Panorama da Aqüicultura, v.87, p.51-53, 2005.

SENAPIN, S.; PHEWSAIYA, K.; BRIGGS, M.; FLEGEL, T.W. Outbreaks of infectious myonecrosis virus (IMNV) in Indonesia confirmed by genome sequencing and use of an alternative RT-PCR detection method. Aquaculture, v.266, p.32-38, 2007.

SOTO, M.A.; LOTZ, J.M. Epidemiological Parameters of White Spot Syndrome Virus infections in Litopenaeus vannamei and L. setiferus. Journal of Invertebrate Pathology, v.78, p.9-15, 2001.

SRITUNYALUCKSANA, K.; SRISALA, J.; WANGNAI, W.; FLEGEL, W. Yellow head virus (YHV) transmission risk from commodity shrimp is reduced to negligible levels by normal processing. Aquaculture, v.300, p.32-36, 2010.

VIEIRA, F.N.; PEDROTTI, F.S.; BUGLIONE NETO, C.C.; MOURIÑO, J.L.P.; BELTRAME, E.; MARTINS, M.L.; RAMIREZ, C.; ARANA, L.A.V. Lactic-acid bacteria increase the survival of marine shrimp, Litopenaeus vannamei, after infection with Vibrio harveyi. Brazilian Journal of Oceanography, v.55, p.251-255, 2007.

Received on September 29, 2010 and accepted on May 31, 2011

Pesq. agropec. bras., Brasília, v.46, n.5, p.531-537, maio 2011 